\title{
Clinical and virological characteristics of calves experimentally infected with a Brazilian isolate of bovine viral diarrhea virus type 1a
}

\author{
Aspectos clínicos e virológicos da infecção experimental de bezerros com \\ uma amostra brasileira do vírus da diarreia viral bovina 1a
}

\author{
Luana Marchi Quadros ${ }^{\mathrm{I}}$ José Conrado dos Santos Jardim ${ }^{\text {II }}$ \\ Ingryd Merchioratto ${ }^{\text {II }}$ Mário Celso Sperotto Brum ${ }^{I^{*}}$
}

\section{ABSTRACT}

To study the pathogenicity of the Brazilian bovine viral diarrhea virus (BVDV) type 1a 241.10 isolate, four calves were intranasally inoculated with a viral suspension containing $10^{7.2} \mathrm{TCID}_{50} \mathrm{~mL}^{-1}$. One calf was left uninoculated and kept in contact with the other calves to investigate viral transmissibility. After inoculation, the animals were monitored daily for clinical signs of infection. The presence of the virus in the blood and nasal secretions was confirmed by virus isolation in cell culture. White blood cells were quantified prior to and every 3 days after infection, and the presence of antibodies was checked every 7 days, starting at day 0 until day 42 post-inoculation (pi). After infection, nasal and ocular serous secretions were observed between days 1 and 5 pi, along with a mild cough from days 2 to 4 pi; however, no severe clinical signs were present. Body temperature was slightly elevated between days 4 and 6 pi. The control calf did not develop any of the signs observed in the infected animals. Cell culturemediated virus isolation confirmed viremia between days 4 and 8 pi and the presence of the virus in the nasal secretions between days 1 and 10 pi. All infected animals showed a decrease in white blood cell count. Antibodies could be detected from day 14 pi, and these levels remained high until day 35 pi. The control calf had no viremia, viral presence in nasal secretions, or positive serology, indicating the absence of viral transmission. Thus, isolate BVDV 1a 241.10 has low pathogenicity and transmissibility but retains immunosuppressive capacity.

Key words: calf, experimental infection, pestivirus, bovine, BVDV.

\section{RESUMO}

Com o objetivo de estudar a patogenicidade de uma amostra brasileira do BVDV-1a (241.10), quatro bovinos foram inoculados pela via intranasal com uma suspensão viral contendo $10^{7,2}$ TCID $_{50} \mathrm{~mL}^{-1}$. Um bezerro foi mantido em contato com o grupo infectado para avaliar a transmissibilidade. Após a inoculação, os animais foram monitorados diariamente para observação dos sinais clínicos. A presença de vírus no sangue e na secreção nasal foi confirmada pelo isolamento viral em cultivo celular. A contagem total de leucócitos no sangue foi realizada com intervalos de três dias pré- e pós-infecção e a detecção de anticorpos a cada sete dias, iniciando-se no dia 0 até o dia 42 pós-inoculação (pi). Após a inoculação, não foram observados sinais clínicos evidentes, apenas secreção nasal e ocular serosa entre os dias 1 e 5 pi e tosse discreta entre os dias 2 e 4 pi. A temperatura corporal teve leve aumento entre os dias 4 e 6 pi. $O$ animal controle não desenvolveu os sinais observados no grupo infectado. $O$ isolamento viral indicou presença de viremia entre os dias 4 a 8 pi e excreção viral na secreção nasal entre os dias 1 e 10 pi. Os animais inoculados apresentaram redução na contagem total de leucócitos no sangue. A detecção de anticorpos iniciou-se no dia 14 pi e os níveis mantiveram-se elevados até o dia 35 pi. No animal controle, não foi observada viremia, presença de vírus na secreção nasal e sorologia positiva, demonstrando ausência da transmissão. Assim sendo, conclui-se que a amostra de BVDV 1a 241.10 possui baixa patogenicidade, mantém a capacidade imunossupressora e tem baixa transmissibilidade.

Palavras-chave: bezerros, infecção experimental, pestivírus, bovinos, $B V D V$

\section{INTRODUCTION}

The bovine viral diarrhea virus (BVDV) is a major pathogen of cattle present both in Brazilian herds and cattle worldwide (FLORES et al., 2005; MOENNIG et al., 2005). BVDV infection leads to production and economic losses due to its enteric, respiratory, reproductive, and hemorrhagic clinical

IPrograma de Pós-graduação em Ciência Animal, Universidade Federal do Pampa (UNIPAMPA), Uruguaiana, RS, Brasil.

"Laboratório de Virologia, Curso de Medicina Veterinária, Universidade Federal do Pampa (UNIPAMPA), Campus Uruguaiana, BR 472, km 598, CP 118, 97.508-000, Uruguaiana, RS, Brasil. E-mail: mariobrum@unipampa.edu.br. "Corresponding author. 
manifestations (FLORES et al., 2005; CORTEZ et al., 2006; BIANCHI et al., 2011). It can induce immunosuppression and allows the establishment of secondary infections in the respiratory and enteric systems (POTGIETER, 1995; RIDPATH, 2010).

BVDV is classified under the Pestivirus genus of the Flaviviridae family, has a singlestranded, $12.5-\mathrm{kb}$ positive sense RNA genome, and contains an enveloped icosahedral capsid of 40$60 \mathrm{~nm}$ in diameter (HORZINEK, 1991). Genetic and antigenic variability among members of the pestivirus genus enables their differentiation into four species: Classical Swine Fever virus, Border disease virus, BVDV-1, and BVDV-2. Besides these, four new groups of viruses have also been documented: the Pronghorn, Giraffe, Bungowannah, and Hobi-like virus. Among the new groups, only viruses belonging to the so-called Hobi-like group have been isolated several times, supporting their grouping into a new viral species called BVDV-3. The other three new groups of viruses have only been isolated occasionally and only from wild animals or pigs (BAUERMANN et al., 2013).

In Brazil, BVDVs have been isolated from cases of respiratory, gastric, enteric, mucosal, and hemorrhagic diseases; semen; persistently infected (PI) animals; poorly developed calves; and fetal bovine serum (BOTTON et al., 1998; FLORES et al., 2000; CORTEZ et al., 2006; BIANCHI et al., 2011). Genetic and antigenic characterization of virus samples from these animals indicates a wide variability and a predominant presence of BVDV-1 (54\%), apart from BVDV-2 (34\%) and the Hobi-like virus (12\%) (BOTTON et al., 1998; CORTEZ et al., 2006; BIANCHI et al., 2011; WEBER et al., 2014). The most prevalent subgenotypes in circulation are BVDV-1a (36\%), BVDV-2b (31\%), and BVDV-1d $(10 \%)$ (WEBER et al., 2014; SILVEIRA et al., 2015). The BVDV-2 strain is more prevalent among Brazilian cattle compared with cattle from other regions of the world (WEBER et al., 2014; SILVEIRA et al., 2015). In the early 2000s, the presence of the Hobilike virus was detected in Brazilian herds; however, its prevalence was much less compared with that of BVDV genotypes 1 and 2 (CORTEZ et al., 2006; BIANCHI et al., 2011; WEBER et al., 2014).

Efficient control of BVDV in a herd relies on the identification and removal of PI animals (BOLIN, 1995). Vaccination is used to aid in the control and prevention of BVDV and is used in several countries (HOUE et al., 2006). In Brazil, there are eight commercial vaccines for BVDV and all of them use inactivated strains of BVDV-1 and/ or BVDV-2. However, BVDV vaccination protects only a relatively small portion of the herd, and in many cases, it is not given systematically (FLORES et al., 2005; ANZILIERO et al., 2015). Therefore, the present study aimed to evaluate the pathogenicity of the Brazilian BVDV 241.10 isolate, classified as BVDV-1a, in calves. Determining its clinical and virological parameters is important for understanding the course of infection and for applying appropriate diagnostic and control measures.

\section{MATERIALS AND METHODS}

\section{Cell culture and virus}

All procedures for viral amplification and isolation were performed using Madin-Darby bovine kidney cells (MDBK; ATCC CCL-22) that were routinely monitored by immunofluorescence and determined to be free of pestivirus contamination. MDBK cells were maintained on minimal essential medium (MEM) containing penicillin $\left(1.6 \mathrm{mg} \mathrm{L}^{-1}\right)$ and streptomycin $\left(0.4 \mathrm{mg} \mathrm{L}^{-1}\right)$ (Vitrocell Embriolife, Brazil) and supplemented with 5\% horse serum (BOTTON et al., 1998). The BVDV-1a 241.10 strain was used for animal inoculation (noncytopathic) and the Singer strain (BVDV-1) was used for serological testing. The virus used for experimentally infecting the animals was originally isolated from the blood of an animal belonging to a herd with reproductive problems (BIANCHI et al., 2011). After isolation in cell culture, the $5^{\prime}$ UTR region was sequenced according to WEBER et al. (2014) and the viral isolate was classified as BVDV-1a.

Animals

Five male calves, 2-4 months of age, virus-free, and seronegative for BVDV were used in this experiment. They were housed in a natural paddock $(8 \times 20 \mathrm{~m})$ and a barn $(4 \times 3 \mathrm{~m})$ and were kept without contact with any other ruminants. During the experiment, calves shared all installations, food, and water. Four calves (calves 1, 4, 8, and 9) were intranasally inoculated with $10 \mathrm{~mL}$ of the cell culture suspension containing $10^{7.2} \mathrm{TCID}_{50} \mathrm{~mL}^{-1}$ equally divided in both nostrils (BRUM et al., 2002). One calf (calf 10) was not inoculated but housed with infected animals throughout the experiment. All calves were subjected to an adaptation period of 15 days prior to infection; the day of infection was defined as day 0 post-infection (pi) and the experiment was terminated on day 42 pi. Animals were monitored daily and clinical signs such as degree of alertness, rectal temperature, nasal and eye secretions, presence 
of cough, and stool consistency were recorded and scored as described previously (FALKENBERG et al., 2014). The final score ranged from 0 (absence of any clinical signs) to 16 (severe clinical disease).

Virus isolation

Virus isolation from cell culture was used to verify the presence of the virus in the blood and nasal secretions of the infected animals. Blood samples were collected on days -2 (prior to infection), $0,2,4$, $6,8,10,12$, and 14 pi. Swabs of nasal secretions were taken daily from days -3 to 15 pi and maintained in a medium containing $5 \times$ antibiotics (MEM 5X ATB). Leukocyte samples or nasal swabs $(200 \mu \mathrm{L} /$ well $)$ were inoculated into preformed monolayers of MDBK cells ( 24 well plate) and cultivated every 72 hours. After the third passage, the presence of the virus was detected by indirect immunofluorescence (BOTTON et al., 1998).

White blood cell (WBC) count

Blood samples were collected on days $-3,0,3,6,9,12$, and 15 pi, an aliquot was stained with Türk's solution, and total leukocyte count was performed using a Neubauer chamber (RIDPATH et al., 2013). White blood cell counts on days -3 and 0 pi were considered baseline and used for comparison with those obtained on all other days.

Serology

Serum was isolated from samples collected on days $0,6,14,21,35$, and 42 pi. Presence of anti-BVDV antibodies was evaluated by the virus neutralization (VN) assay against a homologous virus and the standard Singer strain (BOTTON et al., 1998) or by ELISA using antibodies against the anti-p80 nonstructural protein (IDEXX BVDV p80 Ab Test, Maine, USA).

\section{RESULTS}

During the 15-day adaptation period, all animals remained healthy and all clinical signs, if any, were recorded. Only one animal (calf 4) had a unilateral serous discharge from one eye that remained throughout the experiment. This secretion was not found to be associated with the experimental infection and was thus not scored as a relevant clinical sign. Clinical signs of infection were observed in the infected animals between days 1 and 6 pi. The highest clinical score recorded was 4 , which was due to the presence of cough and serous nasal discharge. All calves developed a serous nasal discharge and an eye discharge between days 1 and 5 pi, and a cough between days 2 and 6 pi. Some calves (calves 1, 4, and 9) also had infrequent nasal or ophthalmic secretions and/or cough between days 8 and 13 pi. All animals showed a slight increase in body temperature $\left(39.6^{\circ} \mathrm{C}\right)$ between days 4 and $6 \mathrm{pi}$; however, the increased body temperature was not classified as hyperthermia because it is defined as a body temperature of $>40^{\circ} \mathrm{C}$. The control animal did not show any of the changes observed in the infected animals.

Viral presence in the nasal secretions and blood was confirmed by cell culture and immunofluorescence. The virus was isolated from blood of all infected calves between days 4 and 8 pi, indicating efficient infection. The virus was also present in the nasal secretions of all calves between days 1 and 6 pi. Nasal swabs taken from two animals (calves 8 and 9) between days 9 and 10 pi also showed viral presence. Blood and nasal secretions from the control animal (calf 10) were negative for viral presence throughout the experiment, indicating that there was no virus transmission between the infected calves and the control calf.

Immunosuppressive effects of the virus were evaluated by determining the WBC count. Blood samples for the WBC count were drawn on alternate days and WBC values prior to infection were used to establish baseline counts. All animals showed a reduction in leukocytes at day $3 \mathrm{pi}$, and they remained low until day $12 \mathrm{pi}$. The average reduction in WBCs was 20\%; however, between days 6 and 9 pi, the reduction was more pronounced, reaching $30 \%$ and $37 \%$ in calves 8 and 9, respectively. The control animal did not show any change in WBC count.

The VN and ELISA tests using antibodies against the anti-p80 nonstructural protein were used to evaluate the immune response to infection. All animals were negative for the presence of anti-p80 protein antibodies on days 0 and 6 pi. The initial seroconversion in the infected calves occurred on day 14 pi, and all animals had antibody titers against the homologous virus, which ranged from 20 to 640 $(\mathrm{GMT}=2.9)$, and against the Singer strain, which ranged from 10 to $320(\mathrm{GMT}=2.4)$. Subsequently, antibody titers remained high until day 35 pi in all infected animals and declined thereafter. Serum samples tested by ELISA showed that at day $14 \mathrm{pi}$, only two animals (calves 4 and 9) were positive for anti-p80 antibodies; however, by day 42 pi, all four infected calves tested positive. The control animal, which remained in contact with the infected animals throughout the experiment, did not develop BVDV neutralizing or anti-p80 
antibodies at any time during the experiment, indicating that there was no viral transmission.

\section{DISCUSSION}

Infection with the BVDV-1a 241.10 revealed that this isolate has low pathogenicity and is not transmitted by contact between animals. Previous reports showed that exposure to BVDV may cause a subclinical infection or several clinical manifestations in cattle (BOTTON et al., 1998; BIANCHI et al., 2011). Previously, experimental inoculation of calves with field isolates has been used as a method to examine infection parameters under controlled conditions (BRUM et al., 2002; DECARO et al., 2012; BAUERMANN et al., 2013; RIDPATH et al., 2013); such analyses enable the characterization of many aspects of infection, such as its acute phase and pathogenesis, host immune response, the transmission between animals, and the efficacy of vaccine protection and diagnostic testing (BRUM et al., 2002; BAUERMANN et al., 2013). Several studies have been conducted using this protocol and the results of these studies showed that virulence is highly variable among strains (BRUM et al., 2002; DECARO et al., 2012; RIDPATH et al., 2013). The 241.10 isolate used in the present study belongs to the BVDV-1a type, a subgenotype that is more prevalent in Brazilian herds (CORTEZ et al., 2006; BIANCHI et al., 2011; WEBER et al., 2014; SILVEIRA et al., 2015). Of the three genotypes circulating in Brazil, BVDV-1 is the most frequently isolated (>35\%) (WEBER et al., 2014). Infection with the 241.10 isolate only resulted in an increase in nasal and eye secretions along with cough; none of these are serious clinical manifestations of BVDV. In contrast, severe respiratory signs have been observed in cases of natural BVDV infection (RIDPATH, 2010) probably because discrete and subtle changes in animal health could not be detected by the producers and/or technical staff, facilitating virus dissemination in the herd.

Efficacy of infection in the current study was established when the virus was successfully recovered from the blood (days 4 to 8 pi) and nasal secretions (days 1 to 6 pi) of all inoculated animals. Nevertheless, it is possible that the virus load isolated from nasal discharge samples on day 1 pi was a residue after the inoculation. BVDV infection can cause immunosuppression subsequent to viral replication in mononuclear cells; the latter also facilitates the occurrence of secondary respiratory and enteric infections (POTGIETER, 1995; BAUERMANN et al., 2013; FALKENBERG et al., 2014). In this study, WBCs decreased in all infected animals after day 3 pi, the largest reduction being observed on day 9 pi (20-37\%), and cell counts almost returned to normal by day 15 pi. Immunosuppressive capacity of the virus has been associated with both low and high virulence. Although animals infected with lowvirulence strains had comparatively mild clinical signs and only transient leukopenia, those infected with high-virulence strains developed more distinct clinical signs and showed a greater reduction in leukocytes, which remained low till day 14 pi (RIDPATH et al., 2013).

Despite viremia and the presence of the virus in the nasal secretions of the infected calves, it was not detect BVDV transmission to the control animal. Nasal secretions and blood samples from this animal remained negative or unchanged during virus isolation, WBC analysis, and serological testing throughout the study period (42 days) even though all five calves were kept in direct contact with each other. It is possible that the absence of transmission was because the infected animals were excreting the virus at concentrations lower than that necessary for effective transmission. Such lack of transmission has been described in previous reports of experimental infection (DECARO et al., 2012; RIDPATH et al., 2013) and may be a characteristic of certain strains of this virus. This observation only serves to strengthen the importance of identifying and isolating infected animals in order to prevent the spread of infection (HOUE et al., 2006).

The immune response to the experimental infection was monitored at regular intervals, and the results demonstrated that all the infected calves developed neutralizing antibodies by day 14 pi. In subsequent bleeding, the titer increased until day 35 pi and then decreased by day 42 pi. Serological testing is an additional method to confirm infection, and the patterns observed here are similar to those observed in previous reports of acute BVDV infections (BRUM et al., 2002; DECARO et al., 2012). Serological cross reactivity with the standard Singer strain showed slightly lower titers. This difference in titer is due to antigen diversity and is routinely observed in serological cross reactivity tests (BOTTON et al., 1998). A comparatively larger difference in reactivity or titer is observed when samples are tested against a different virus species (BOTTON et al., 1998), and this characteristic is important in routine diagnostic testing and for assessing the effectiveness of vaccines (FLORES et al., 2005; ANZILIERO et al., 2015). Sera from all infected animals collected on days 14 
and 42 pi were tested for the presence of anti-p80 antibodies by ELISA. Although only two animals (calves and 8) had antibodies against p80 on day 14 pi, all samples collected on day 42 pi were positive for anti-p80 antibodies. However, a comparison of the results obtained using both techniques revealed that the VN test was able to detect the presence of the antibodies sooner than ELISA could. Nevertheless, ELISA is widely used for diagnosis because of its technical characteristics and its ability to detect low levels of nonstructural proteins conserved among isolates (MOENNIG et al., 2005).

The basic method of controlling the spread of BVDV in a herd relies on the identification and removal of PI animals, which also helps avoid fetal infection (MOENNIG et al., 2005). Infected animals can be identified by diagnostic methods such as virus isolation, ELISA, immunohistochemistry of ear biopsy samples, or PCR; however, these methods are available only in a limited number of Brazilian diagnostic laboratories (FLORES et al., 2005). Considering the size of the national herd and the fact that the demand for these tests in the field has increased in recent years, their availability, nonetheless, still remains very low (FLORES et al., 2005). Fetal infection is controlled by preventing pregnant cows from coming into contact with the virus or by vaccine immunization (BOLIN, 1995). Most of the BVDV vaccines available in Brazil use type 1 and/or 2 viruses with questionable immunogenicity (ANZILIERO et al., 2015). Importantly, a study showed that PI and transitorily infected animals were still present in vaccinated herds, indicating that vaccination alone is insufficient for eliminating infection (DEZEN et al., 2013). This situation, combined with the presence of low-pathogenicity strains such as those used in this study, makes the identification of clinical cases difficult and may contribute to the silent spread of BVDV in Brazilian herds.

\section{CONCLUSION}

The BVDV-1a 241.10 virus has low pathogenicity and transmission efficacy in calves. In infected calves, the virus caused cough and slightly increased ocular and nasal secretions; additionally, serum conversion occurred on day 14 pi and the virus maintained its immunosuppressive capacity. Thus, we demonstrated that BVDV infections could occur in cattle without the manifestation of clinical signs. Therefore, control measures must always aim to identify sick and PI animals as they are considered the main source of herd infection.

\section{ACKNOWLEDGMENTS}

The authors would like to thank the Setor de Virologia of the Universidade Federal de Santa Maria (UFSM) for providing the virus and cell cultures, and Prof. Francieli W. S. Cibin (UNIPAMPA) for helping with hematologic evaluations. Additional acknowledgements go to Fundação de Amparo à Pesquisa do Estado do Rio grande do Sul (FAPERGS ARD 1002220) and Conselho Nacional de Desenvolvimento Científico e Tecnológico (CNPq - 486302/2013-0) for financial support.

\section{REFERÊNCIAS}

ANZILIERO, D. et al. Serological response to bovine herpesvírus 1 and 5 and bovine viral diarrea virus induced by comercial vacines. Ciência Rural, v.45, n.1, p.58-63, 2015. Available from: $<$ http://www.scielo.br/scielo.php?script=sci arttext\&pid=S010384782015000100058\&lng=en\&nrm=iso $>$. Accessed: Mar. 12, 2015. doi: $10.1590 / 0103-8478 \mathrm{cr} 20130167$.

BAUERMANN, F.V. et al. Hobi-like viruses: an emerging group of pestiviruses. Journal of Veterinary Diagnostic Investigation, v.25, n.1, p.6-15, 2013. Available from: $<$ http://vdi. sagepub.com/content/25/1/6.full>. Acessed: Feb. 10, 2013. doi: $10.1177 / 1040638712473103$.

BIANCHI, E. et al. Genotypic and antigenic profile of bovine viral diarrhea virus isolates from Rio Grande do Sul, Brazil (2000-2010). Pesquisa Veterinária Brasileira, v.31, n.8, p.649-655, 2011. Available from: <http://www.scielo.br/scielo. php?script $=$ sci_arttext\&pid=S0100-736X2011000800003\&lng $=$ en\&nrm=iso\&tlng=pt $>$. Accessed: Jan. 15, 2012. doi: 10.1590/ S0100-736X2011000800003.

BOLIN, S. Control of bovine viral diarrhea virus infection by use of vaccination. Veterinary Clinics of North America: Food Animal Practice, v.11, n.3, p.615-626, 1995.

BOTTON, S.A. et al. Antigenic characterization of Brazilian bovine viral diarrhea virus isolates by monoclonal antibodies and cross-neutralization. Brazilian Journal of Medical and Biological Research, v.31, n.11, p.1429-1438, 1998. Available from: <http:// www.scielo.br/scielo.php?script $=$ sci arttext\&pid=S0100-879X19 98001100011\&lng=en\&nrm=iso $>$. Accessed: Feb. 27, 2014. doi: 10.1590/S0100-879X1998001100011

BRUM, M.C.S. et al. Gastroenteric and respiratory disease in calves inoculated with Brazilian isolates of bovine viral diarrhea vírus type 2 (BVDV 2). Ciência Rural, v.32, n.5, p.803-820, 2002. Available from: $<$ http://www.scielo.br/scielo. php? script $=$ sci_arttext\&pid $=$ S0103-84782002000500012\&lng $=$ en $\& n r m=$ iso $>$. Accessed: Apr. 03, 2014. doi 10.1590/S010384782002000500012 .

CORTEZ, A. et al. Genetic characterization of Brazilian bovine viral diarrhea virus isolates by partial nucleotide sequencing of the 5'UTR region. Pesquisa Veterinária Brasileira, v.26, n.4, p.211216, 2006. Available from <http://www.scielo.br/scielo. php?script $=$ sci_arttext\&pid $=$ S0100-736X2006000400005\&lng =en\&nrm=iso $>$. Accessed: Jan. 27, 2014. doi 10.1590/S0100$736 \times 2006000400005$.

DECARO, N. et al. Experimental infection of cattle, sheep and pigs with "Hobi"-like pestivirus. Veterinary Microbiology, v.155, p.165-171, 2012. Available from: <http://www.sciencedirect.com/ 
science/article/pii/S0378113511004767> . Accessed: Jan. 27, 2014. doi:10.1016/j.vetmic.2011.08.030

DEZEN, S. et al. Bovine viral diarrhea virus (BVDV) infection profile in a high production dairy herd with vaccination program against BVDV. Pesquisa Veterinária Brasileira, v.33, n.2, p.141-147, 2013. Available from $<\mathrm{http}$ :/www.scielo.br/scielo.php?script $=\mathrm{sci}$ arttext\&pid $=\mathrm{S} 0100-736 \mathrm{X} 2013000200002 \& \operatorname{lng}=\mathrm{en} \& \mathrm{nrm}=\mathrm{iso}>$. Accessed: 12, Jun, 2014. doi: 10.1590/S0100-736X2013000200002.

FALKENBERG, S.M. et al. Changes observed in the thymus and lymph nodes 14 days after exposure to BVDV field strains of enhanced or typical virulence in neonatal calves. Veterinary Immunology and Immunopathology, v.160, n.1-2, p.70-80, 2014. Available from: $<$ http:// www.sciencedirect.com/science/article/pii/S0165242714000932>. Accessed: 5 Apr. 2014. doi: 10.1016/j.vetimm.2014.03.018.

FLORES, E.F. et al. Bovine viral diarrhea virus (BVDV) infection in Brazil: history, current situation and perspectives. Pesquisa Veterinária Brasileira, v.25, n.3, p.125-134, 2005. Available from: $<$ http://www.scielo.br/scielo.php?script=sci arttext\&pid $=$ S0100-736X2005000300002\&lng $=$ en $>$. Accessed: 30 Jul. 2015. doi: 10.1590/S0100-736X2005000300002.

HORZINEK, M.C. Pestivirus: taxonomic perspectives. Archive of Virology, (suppl, 3), p.1-5, 1991.

HOUE, H. et al. Test strategies in bovine viral diarrhea virus control and eradication campaigns in Europe. Journal of Veterinary Diagnostic Investigation, v.18, n. 5, p.427-436, 2006. Available from <http://vdi.sagepub.com/content/18/5/427.full.pdf + html $>$. Acccessed: 30, Jul. 2015. doi:10.1177/104063870601800501.
MOENNIG, V. et al. BVD control in Europe: current status and perspectives. Animal Health Research Reviews, v.6, n.1, p.6374, 2005. doi: 10.1079/AHR2005102.

POTGIETER, A.N.D. Immunology of BVDV. In: Bovine Viral Diarrhea virus. Veterinary Clinics of North America: Food Animal Practice, v.11, n. 3, p.501-520, 1995.

RIDPATH, J. The contribution of infections with bovine viral diarrhea viruses to bovine respiratory disease. Veterinary Clinics of North America: Food Animal Practice, v.26, n.2, p.335-348, 2010. Available from: <http://www.sciencedirect. com/science/article/pii/S0749072010000095>. Accessed: 30, Jul. 2015. doi:10.1016/j.cvfa.2010.04.003.

RIDPATH, J. et al. Comparison of acute infection of calves exposed to a high virulence or low virulence bovine viral diarrhea virus or a Hobi-like virus. American Journal of Veterinary Research, v.74, n.3, p.438-442, 2013. doi: 10.2460/ajvr.74.3.438

WEBER, N.M. et al. High frequency of bovine viral diarrhea virus type 2 in Southern Brazil. Virus Research, v.191, p.117-124, 2014. Available from: $<$ http://www.sciencedirect.com/science/article/pii/ S016817021400313X>. Accessed: 20, Aug. 2015. doi:10.1016/j. virusres.2014.07.035.

SILVEIRA, S. et al. Genetic diversity of Brazilian bovine pestiviruses detected between 1995 and 2014. Transboundary Emerging Disease, Article first published online: 28 Sept. 2015. Available from: <http://onlinelibrary.wiley.com/doi/10.1111/ tbed.12427/full>. Accessed: 19, Nov. 2015. doi: 10.1111/ tbed. 12427 . 